\title{
New record of Momonidinae (Acari: Hydrachnidiae: Momoniidae) from
}

\section{Japan}

\author{
Shizuko MORIMOTO ${ }^{1}$ and Hiroshi ABÉ ${ }^{2}$ * \\ ${ }^{1}$ Museum of Nature \& Human Activities, Sanda, Hyogo, 669-1546 Japan \\ ${ }^{2}$ Biological laboratory, College of Bioresource Sciences, Nihon University, Fujisawa, 252-0880 \\ Japan
}

(Received 16 May 2019; Accepted 17 July 2019)

\begin{abstract}
Momonides landbergi Lundblad, 1971 is newly recorded from Iriomote Island, Okinawa, southern Japan. This is the first record of the subfamily Momonidinae from Japan. Characteristics of the present Japanese specimens accord well with those of the specimens from Indonesia originally described by Lundblad (1971), except for somewhat smaller number of genital acetabula of the Japanese specimens. The present record extends northward the worldwide distribution of M. landbergi to near the Palearctic region.
\end{abstract}

Key words: new record, Momonides landbergi, Momonidinae, Hydrachnidiae, Japan

\section{INTRODUCTION}

The family Momoniidae is placed in the superfamily Arrenuroidea in the subcohort Hydrachnidiae (Lindquist et al., 2009). The Momoniidae consist of five subfamilies, Momoniinae, Cladomomoniinae, Cyclomomoniinae, Momonidinae and Stygomomoniinae, containing 59 species in 13 genera.

The family inhabits rivers, lakes, springs, and subterranean waters in all biogeographical regions of the world (Cook, 1974; Smith, 1991). In Japan, so far only three species in the subfamily Stygomomoniinae, listed below, have been recorded from well water in Hokkaido, Tokyo, Ishikawa, and Hyogo (Abé, 2005).

Stygomomonia (Stygomomonia) rotunda Imamura, 1956

S. (S.) hachiojiensis Imamura, 1959

S. (Allomomonia) kantoensis Imamura, 1959

Recently, one of the authors (S. Morimoto) collected two specimens of the family Momoniidae from a stream on Iriomote Island in Okinawa, southern Japan. The taxonomic identification of these momoniid specimens is executed in the present study.

* Corresponding author: e-mail: abe.hiroshi@nihon-u.ac.jp

DOI: $10.2300 /$ acari.28.85 


\section{MATERIALS AND METHODS}

On March 21 and October 21 in 2016, S. Morimoto collected two momoniid specimens in Nishi Funatsuki River at $10 \mathrm{~m}$ above sea level on Iriomote Island in Okinawa, southern Japan (Fig. 1). The river, about $10 \mathrm{~m}$ in width and $40 \mathrm{~cm}$ in maximum depth, flows swiftly from an upstream dam. The mites were collected by means of sweeping the riverbed using a plankton net with a mesh of $300 \mu \mathrm{m}$ aperture and preserved in Imamura's fluid (Imamura, 1965). Thereafter, the mites were mounted in glycerin jelly, and the cover slips were sealed with Canada balsam

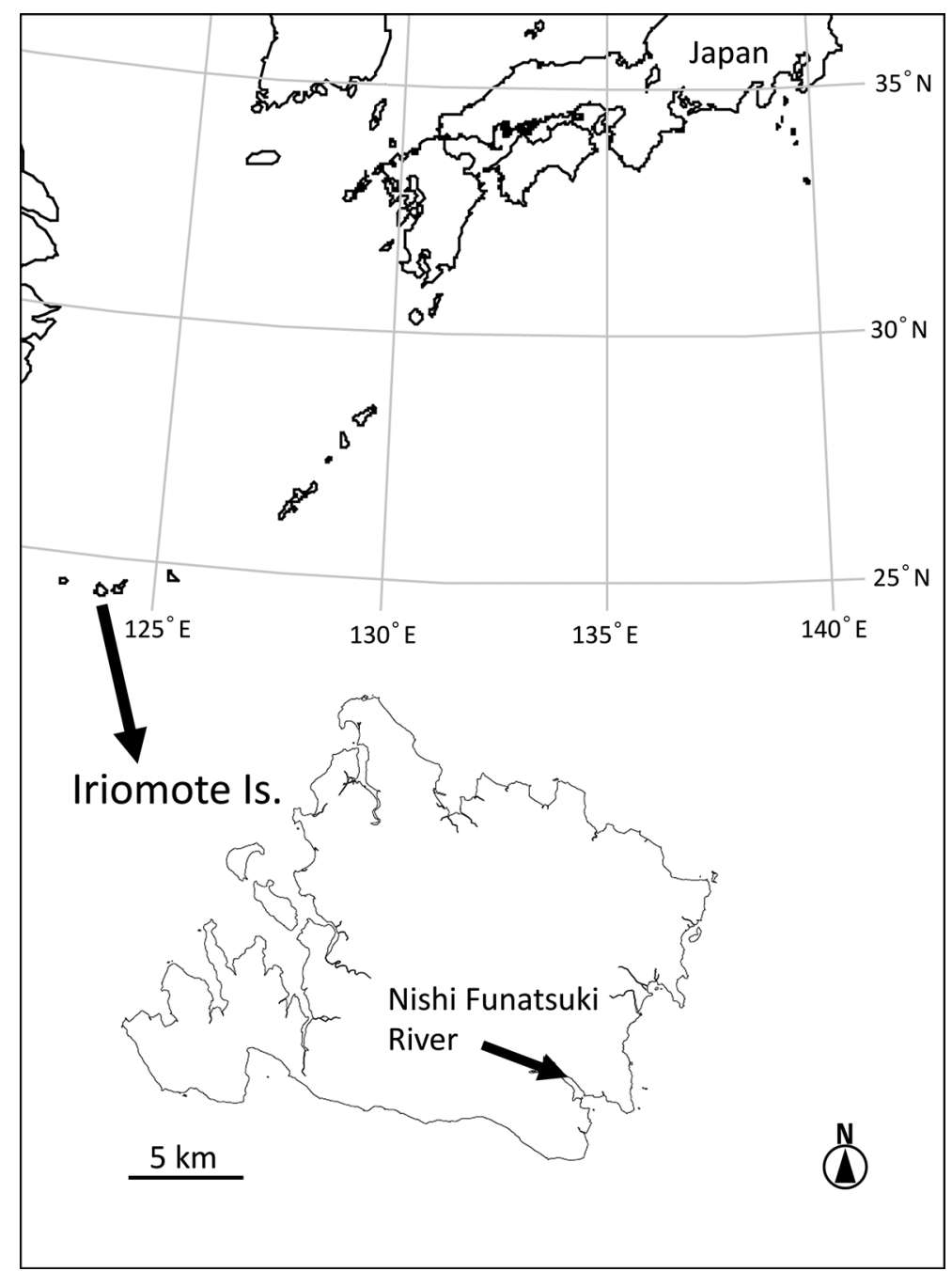

Fig. 1. Provenance of the material used in the present study. 

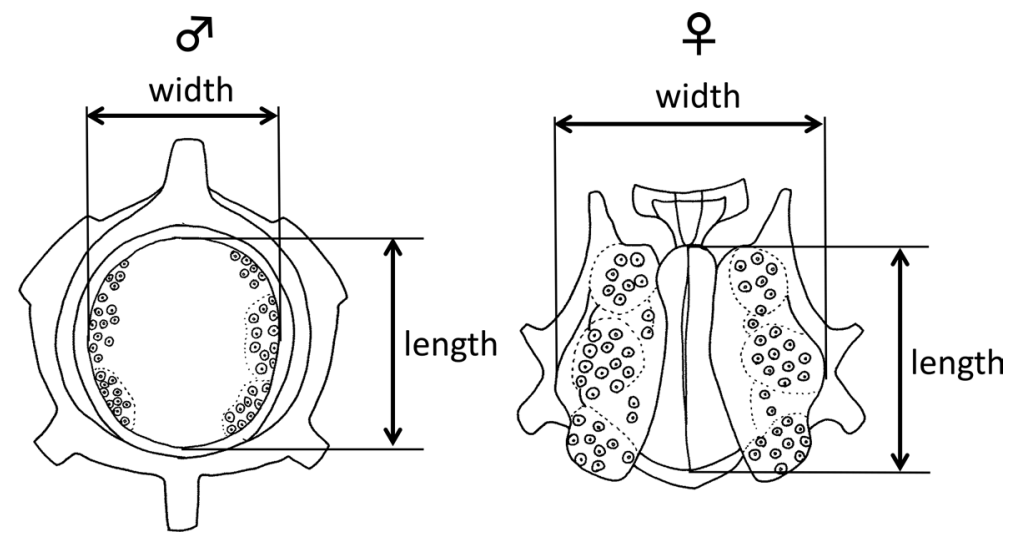

Fig. 2. Schematic diagram of the genital field of male and female for measurements of length and width.

under a stereomicroscope. The mites were investigated under a light microscope.

The body parts were measured in the following scheme: (1) idiosoma: length-from the anterior-most margin of the first coxal plate to the terminal end of the idiosoma, width - at the widest point; (2) idiosomal plate or sclerite: length - from the anterior- to posterior-most margins along the longitudinal median axis, width — at the widest point; (3) leg segments: length — straight dorsal length from the proximal base to the distal end; (4) palp segments: length — straight dorsal and ventral length from the proximal base to the distal end, height - at the highest point; (5) chelicera: length - straight ventral length from the proximal base to the distal end; (6) genital field (Fig. 2): length - from the anterior to posterior margins of the gonopore along the longitudinal median axis, width - at the widest point of the gonopore in the male and of the genital plate in the female; (7) distance among idiosomal plates, gonopore, and anal papilla: distance between the nearest margins along the longitudinal median axis.

Figures were drawn based on photos taken with a digital camera attached to an eyepiece of the microscope, and measurements were made with an ocular micrometer.

The material has been deposited in the Museum of Nature \& Human Activities, Sanda, Hyogo, 669-1546 Japan.

\section{RESULTS}

As a result of precise taxonomic examination, the specimens were identified as Momonides landbergi Lundblad, 1971. The genus Momonides is the only genus in the subfamily Momonidinae. Therefore, this is as well the first record of the subfamily Momonidinae from Japan. The taxonomic characteristics of M. landbergi are outlined below based on the Japanese male and female specimens. Measurements are given in micrometers $(\mu \mathrm{m})$. 
Subfamily Momonidinae Lundblad, 1941

(New Japanese name: Madara-momodani-aka)

Genus Momonides Lundblad, 1941

(New Japanese name: Madara-momodani-zoku)

Momonides landbergi Lundblad, 1971

(New Japanese name: Tsumeboso-madara-momodani)

Momonides landbergi Lundblad, 1971: 351-352, Fig. 50, plates XXVII-128, XXVIII-129, 130; Cook, 1974: 786, Fig.1657; Smit and Pešić, 2014: 64-66.

(Figs. 3-18)

Specimens examined: one female, Nishi Funatsuki riverbed $\left(24^{\circ} 18^{\prime} 10^{\prime \prime} \mathrm{N}, 123^{\circ} 51^{\prime} 34^{\prime \prime} \mathrm{E}\right)$, Komi, Taketomi, Yaeyama District, Okinawa Prefecture, Japan, March 21, 2016, S. Morimoto leg.; one male, same locality as above, Oct. 21, 2016, S. Morimoto leg.

Male (MNHAH A2-013573): Body brownish with distinct red eyes (Fig. 3). Dorsal length 418, width 372, L/W 1.12; ventral length 474.

Idiosoma oval, entirely covered with several irregularly ramiform porous sclerites linked with soft membranous cuticle (Fig. 4). First coxa protruding anteriorly from idiosoma (Fig. 5). Anterior coxal group (first and second coxae) 150 long, 210 wide (both sides), partly broken. Posterior coxal group (third and fourth coxae) 193 long, 260 wide. Anterior and posterior coxal groups separated from each other at intervals of 10-25. Elongate single ramiform sclerite 133 long, 55 wide, placed between right and left posterior coxal groups (Fig. 5). Genital field subterminal, placed posteriorly to fourth coxa (Fig. 5). Gonopore, 70 long, 56 wide, with three pairs of acetabula subdivided into numerous smaller acetabula arranged in three distinct groups, first (= anterior) pair each with 4-5 acetabula, second pair with 9-10 acetabula, third pair with 8-9 acetabula, surrounded by a sclerotized ring bearing six-lobed outer extensions (Fig. 6). Distance from posterior margin of fourth coxal plate to anterior margin of gonopore 10. Anal field papilliform, placed terminal on venter (Fig. 5). Distance from posterior margin of gonopore to tip of anal papilla 75 .

Palp five segmented (Fig. 8). Femur longer than tibia. Ratio of dorsal length of femur to tibia 1.13. Length and height of each segment given in Table 1. Trochanter and femur with one and five dorsal setae, respectively. Genu with four dorsal setae. Tibia with two dorsal setae and two robust ventral spines. Tarsus with two dorsal and one ventral setae, ventro-distally with two short heavy spines, and one long curved distal claw (Fig. 8). Chelicera claw-like in form (Fig. 9), consisting of two segments. Basal segment 65 long, claw segment 25 long.

Legs with several kinds of setae (Figs. 10-13) and entirely ornamented with regular honeycomb pattern (Fig. 14). Tibia of first leg elongate and robust (Fig. 10). Length of each segment given in Table 2. Dorsal length of tarsus of first leg exceeding a half-length of tibia. Ratio of dorsal length of tarsus to tibia of first leg 0.55 .

First tarsus gently raised in proximal portion, bearing a distally curving single claw with two clawlets at the middle of the shaft (Fig. 15). Claw of first tarsus 58 long. Other tarsalia bearing a 

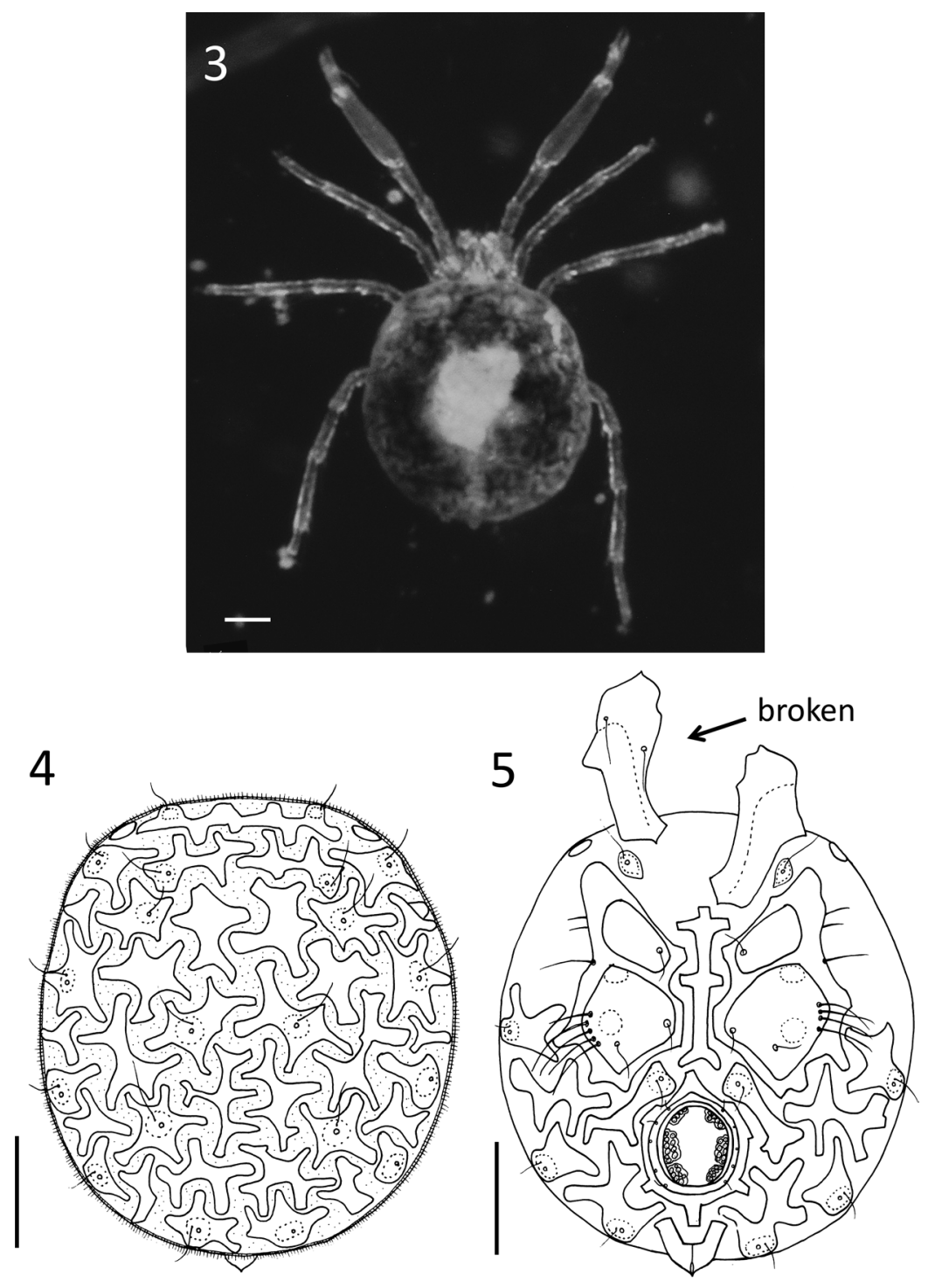

Figs. 3-5. Momonides landbergi. 3: Dorsal view of the unmounted female, 4: dorsal view of idiosoma (male), 5: ventral view of idiosoma (male). Scale bars: $100 \mu \mathrm{m}$.

pair of trifurcate bending claws with thin ventral claw-blade (Fig. 16).

Female (MNHAH A2-013574): Body oval. Dorsal length 530, width 490, L/W 1.08; ventral length 576. General characteristics similar to the male except for the genital field.

Anterior coxal group 158 long, 200 wide. Posterior coxal group 215 long, 263 wide. Elongate single ramiform sclerite 136 long, 57 wide. Genital field placed posteriorly to fourth coxa. 

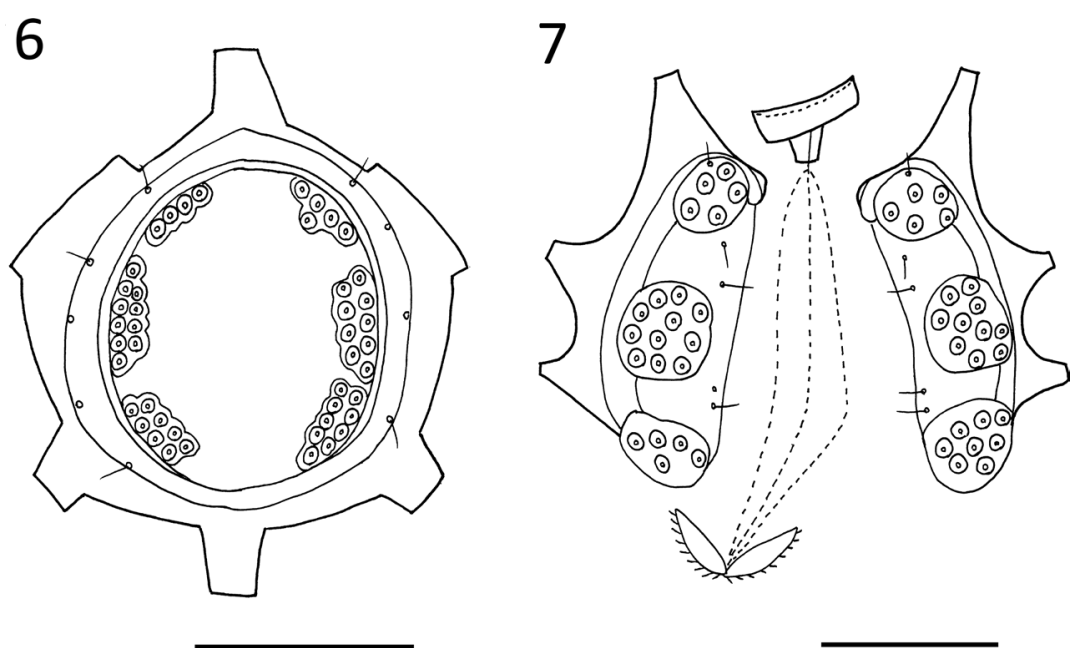

Figs. 6-7. Momonides landbergi. 6: Genital field (male), 7: genital field (female) (partly broken). Scale bars: $50 \mu \mathrm{m}$.

Table 1. Measurements of the left palp segments in the male.

\begin{tabular}{lccccccc}
\hline Palp segment & Trochanter & Femur & Genu & Tibia & Tarsus & & Total \\
\cline { 3 - 5 } \cline { 6 - 7 } Dorsal length & 25 & 45 & 28 & 40 & 35 & & 173 \\
Ventral length & 16 & 30 & 20 & 33 & 35 & & 134 \\
Maximum height & 20 & 33 & 28 & 25 & 12 & & - \\
\hline
\end{tabular}

Gonopore (partly broken), 120 long, 108 wide, with numerous smaller acetabula arranged in three distinct groups, first (= anterior) pair each with 5 acetabula, second pair with 10-11 acetabula, third pair with 5-8 acetabula (Fig. 7), surrounded by pregenital and postgenital sclerites as well as right and left sclerites each bearing three-lobed outer extensions (Fig. 7). Distance from posterior margin of fourth coxa to anterior margin of gonopore 61. Distance from posterior margin of gonopore to tip of anal papilla 40 .

Measurements of leg segments given in Table 2. Ratio of dorsal length of tarsus to tibia of first leg 0.56. First tarsus with a single claw 73 long, 9 high (Fig. 17). Other tarsus bearing a pair of trifurcate claws (Fig. 18).

\section{Remarks}

At present, the genus Momonides contains four species: Momonides trabecularis Lundblad, 1941; M. lundbladi Angelier, 1951; M. landbergi Lundblad, 1971; and M. ghanaensis Smit, 2012. Momonides landbergi is different from its congeners as follows: (1) a sclerite surrounding gonopore of the male with six lobed outer extensions; (2) dorsal length of first tarsus exceeding a half-length of tibia; (3) first tarsus not sharply raised in proximal portion; (4) single claw of first tarsus elongate and with two ventral clawlets at the middle of the shaft. 

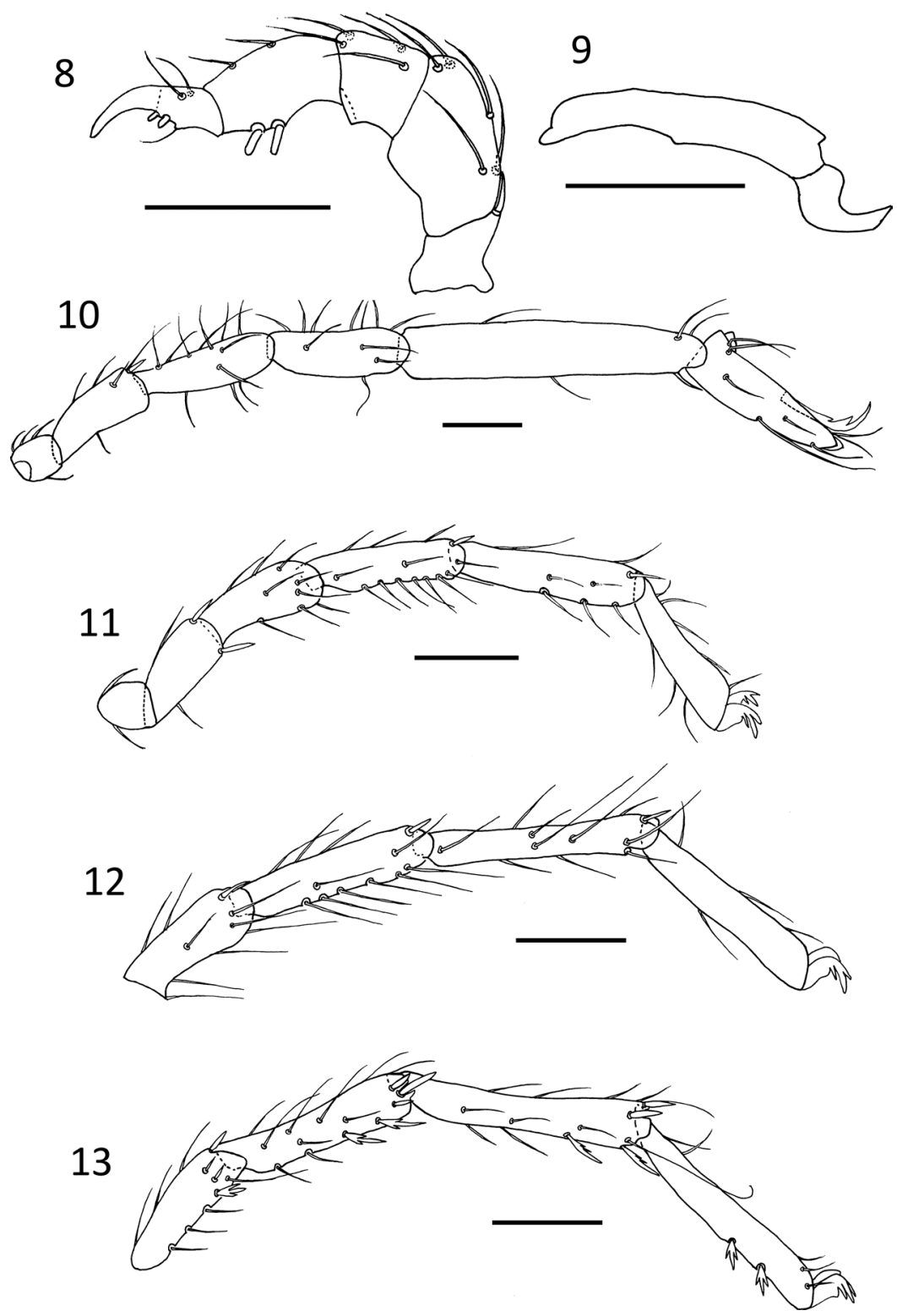

Figs. 8-13. Momonides landbergi. 8: Left palp (male), 9: right chelicera (male), 10: right first leg (male), 11: right second leg (male), 12: telofemur to tarsus of the right third leg (male), 13: telofemur to tarsus of the right fourth leg (male). Scale bars: $50 \mu \mathrm{m}$.

Table 2. Dorsal length of the first leg segments.

\begin{tabular}{ccccccccc}
\hline Leg segment & Trochanter & Basifemur & Telofemur & Genu & Tibia & Tarsus & & Total \\
\cline { 3 - 7 } \cline { 4 - 6 } Male & 28 & 78 & 95 & 94 & 205 & 112 & & 612 \\
Female & 28 & 88 & 108 & 105 & 233 & 130 & 692 \\
\hline
\end{tabular}



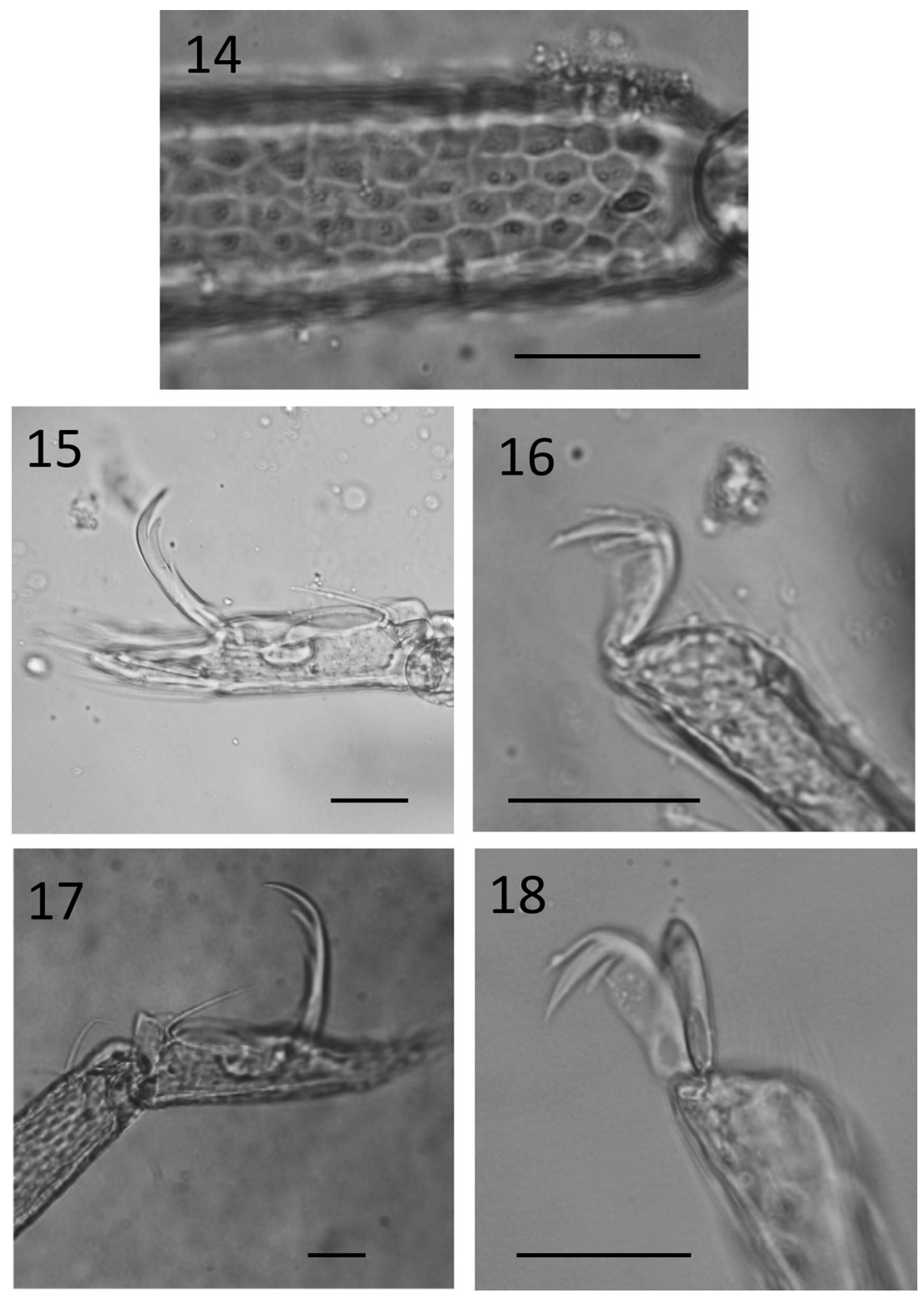

Figs. 14-18. Momonides landbergi. 14: Surface structure of the right first tibia (male) 15: tarsus of the left first leg (male), 16: tip of the tarsus of the left second leg (male), 17: tarsus of the left first leg (female), 18: tip of the tarsus of the right fourth leg (female). Scale bars: $25 \mu \mathrm{m}$. 

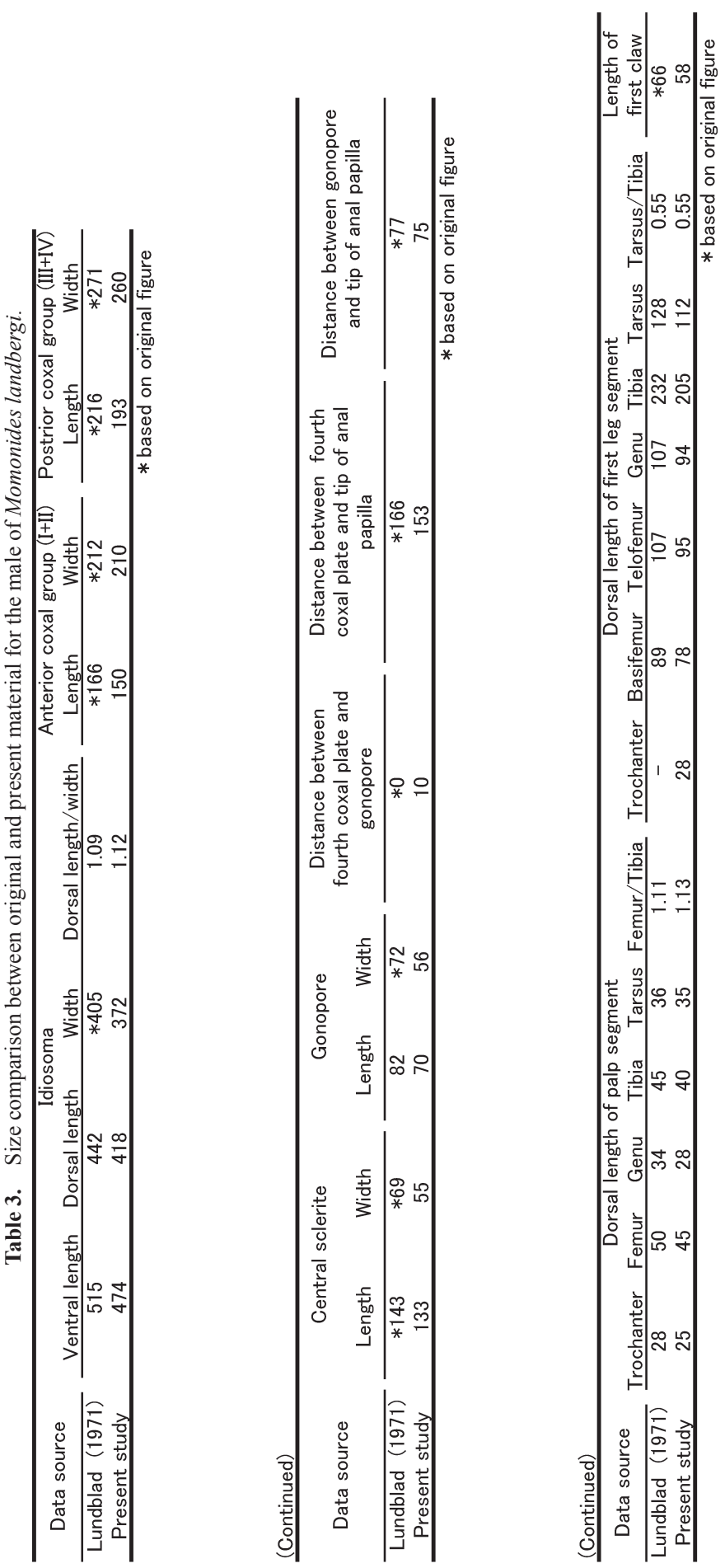
Momonides landbergi was originally described by Lundblad (1971) based on male and female specimens from Java. There are no distinct morphological differences between the Japanese male in the present study and the male described by Lundblad (1971). However, it should be noted that the male in Cook (1974) has somewhat larger number of acetabula than the Japanese male. Judging from the figure 1657 in Cook (1974), the male has three pairs of acetabular groups: first (= anterior) pair each with 7-8 acetabula (4-5 in Japanese male), second pair with 13 acetabula (9-10 in Japanese male), third pair with 12 acetabula (8-9 in Japanese male). Such an inconsistency seems to be geographic variation.

Size comparisons of each body part between the male in the original description (Lundblad, 1971) and the present Japanese male specimen are given in Table 3. Such a comparison for the female was unfortunately not practicable because of the partly destroyed condition of the Japanese female specimen and the lack of a description of detailed measured values and figuration of the female by Lundblad (1971). Based on the size comparison of each body part in the male, there are no clear differences between the Japanese specimen and the original description.

Momonides landbergi was originally recorded from a waterfall in Java, an island of Indonesia,

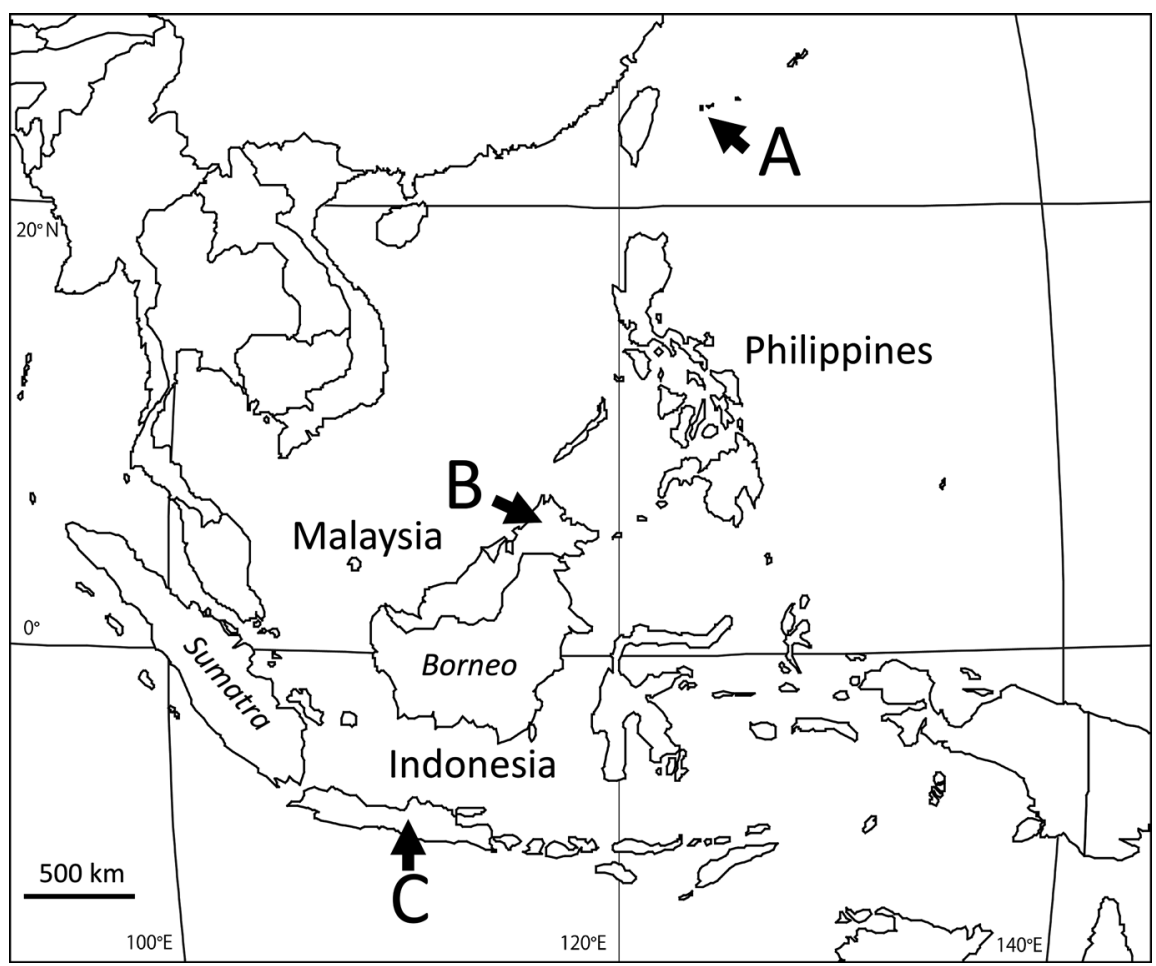

Fig. 19. Worldwide distributions of Momonides landbergi. A: Nishi Funatsuki River, Iriomote Island, Okinawa, Japan (present study); B: Kipungit River, Poring Hot Springs, Mt. Kinabalu; unnamed creek along Bansadon Trail, Inobong, Crocker Range, Borneo Island, Malaysia (Smit and Pešić, 2014); C: Kali Larangan River, Pagilaran, Java Island, Indonesia (Lundblad, 1971). 
by Lundblad (1971). Thereafter, the species was also recorded from a river and a creek in Borneo, an island of Malaysia in the Oriental region, by Smit and Pešić (2014). Consequently, the present study extends northward the worldwide distribution of M. landbergi nearly to the Palearctic region (Fig. 19).

The following water mites were collected together with M. landbergi, in Iriomote Island: Hydrodroma sp., Oxus sp., Torrenticola spp., Albia sp., Axonopsis sp., Atractides sp., Hygrobates spp., Neumania sp., Arrenurus sp., and Mideopsis sp.

\section{ACKNOWLEDGMENTS}

We are grateful to Dr. Tomiko Ito (Hokkaido Aquatic Biology) for her kind assistance in collecting the materials from several streams on Iriomote Island. We dedicate heartfelt thanks to two anonymous reviewers for their valuable comments in improving a previous version of manuscript.

\section{REFERENCES}

Abé, H. (2005) Annotated checklist of Japanese water mites (Acari: Prostigmata: Hydracarina). Acta Arachnologica, 54: $111-145$.

Angelier, E. (1951) Diagnoses sommaires d'Hydracariens psammiques noveaux de Corse. Bulletin du Muséum, Paris, $\left(2^{\mathrm{e}}\right.$ série), 23: 508-510.

Cook, D. R. (1974) Water mite genera and subgenera. Memoirs of the American Entomological Institute, 21: 1-860.

Imamura, T. (1956) Some subterranean water mites from Hyogo Prefecture, Japan. Comptes Rendus Première Congrès Internationale de Spéléologie, 3: 193-214.

Imamura, T. (1959) Water-mites (Hydrachnellae) of subterranean waters in Kanto District, Japan. Acarologia, 1: 426-451.

Imamura, T. (1965) II. A case of water mites, 2. Preservation and mounting, 4. Collection and Experimental Techniques. In: Mites, An Introduction to Classification, Bionomics and Control of Acarina. (ed., Sasa, M.), p. 34, University of Tokyo Press, Tokyo. (In Japanese)

Lindquist, E. E., G. W. Krantz and D. E. Walter (2009) Chapter 8. Classification. In: A manual of acarology. (eds., Krantz, G. W. and D. E. Walter), pp 97-103, Texas Tech University Press, Lubbock.

Lundblad, O. (1941) Neue Wassermilben. Vorläufige Mitteilung. Entomologisk Tidskrift, 62: 97-121.

Lundblad, O. (1971) Weitere Beiträge zur Kenntnis der Fliesswassermilben Javas. Arkiv för Zoologi, (Serie 2), 23: 293 359.

Smit, H. (2012) First record of the water mite genus Momonides Lundblad from the Afrotropical region (Acari: Hydrachnidia: Momoniidae). Systematic \& Applied Acarology, 17: 346-348.

Smit, H. and V. Pešić (2014) Water mites from Mount Kinabalu and the Crocker Range, Borneo, Malaysia (Acari: Hydrachinidia), with the description of 34 new species. Zootaxa, 3876: 1-71.

Smith, I. (1991) North American water mites of the family Momoniidae Viets (Acari: Arrenuroidea). IV. Revision of species of Stygomomonia (sensu stricto) Szalay, 1943. The Canadian Entomologist, 123: 501-558.

Viets, K. (1926) Versuch eines Systems der Hydracarinen. Zoologischer Anzeiger, 69: 188-199.

\section{摘要}

マダラモモダニ亜科（ダニ亜綱 : ミズダニ亜団：モモダニ科）の日本初記録

森本静子 (兵庫県立人と自然の博物館) - 安倍 弘 (日本大学生物資源科学部) 
国内で初めてツメボソマダラモモダニ Momonides landbergi Lundblad, 1971 が沖縄県西表島 の河川から記録された。これは，マダラモモダニ亜科 Momonidinae の日本初記録である. 本 種の日本産個体は Lundblad（1971）により記載されたインドネシア産個体より性感体の数が 若干少なかったが，他の分類形質に大きな違いは見られなかった．今回の西表島からの記録 により，本種の分布域が東洋区南部から旧北区付近にまで広がった。 